PROBLEMS

OF MANAGEMENT IN THE $21^{\text {st }}$ CENTURY

Vol. 16, No. 2, 2021

\section{INTEGRATED BORDER MANAGEMENT AS A VECTOR TO COMBAT ILLEGAL IMMIGRATION IN MOZAMBIQUE}

\author{
Zainadine João Danane \\ Technical University of Mozambique, Mozambique \\ E-mail: zainadinedanane@gmail.com
}

\begin{abstract}
This research intends to understand how an integrated border management can contribute to combat illegal immigration in Mozambique, and the evils that come from this irregular entry, as well as the related crimes associated with it. Taking into account the sad events perpetrated by the terrorists in Cabo - Delgado, which has a participation of foreign citizens, it is assumed that some of these citizens have entered illegally or enticed the border authorities to enter Mozambique through illegal means, therefore, it is interesting to understand how the management and control of borders is carried out. It is important to understand how the Mozambican authorities have managed the phenomenon of illegal immigration, even recognizing that some of the borders are porous. The permanent articulation with the various forces involved in border control, in ways that each one of them appropriates illegal immigration, may be the horizon to follow, so that there is no violation of borders, preserving national sovereignty, as efficiency and the effectiveness of the different sectors involved in the border process, can be achieved as long as the different entities that control the border carry out their activities in a coordinated manner, allowing for an ever-increasing flow of commercial transactions. The research is bibliographical, qualitative, using the technique of direct observation, and data provided by the General Directorate of Migration of Mozambique.
\end{abstract}

Keywords: border management, illegal immigration, related crimes, Mozambican Legal Framework

\title{
Introduction
}

Mozambique is located south of the equator, in the southern Africa region, in the southwest of the African continent, bordering on the north by Tanzania, northwest by Malawi and Zambia, east by the Indian Ocean, west by Zimbabwe, Africa South and Swaziland, and to the south with South Africa.

According to da Barca (1992) and Francisco (2015) Mozambique has a surface of 799,380 $\mathrm{km} 2$ of which 13,000 km2 are occupied by inland waters that include lakes, reservoirs and rivers, and an enormous extension of borders of about $4,212 \mathrm{~km}$, of which $63.8 \%$ correspond to the land border, $28.6 \%$ the river border and $7.6 \%$ the lake border, but also the vast coastal extension $(2,780 \mathrm{~km})$, which contributes to the regular and/or irregular entry of immigrants, associated with this, the porosity factor that characterizes state borders.

The porosity of borders posts national internal security challenges to the country, which national borders, as well as simplified Posts, may be being used by professional migrant smuggling networks, including unaccompanied migrant children, human trafficking, smugglers from wild animals and drug trafficking.

According to Cadeado et al (2009), migration has always been constant in human history, having as its main causes political, social, economic reasons, as well as the existence of natural disasters. However, the search for better living and working conditions were always determining factors for the occurrence of migrations. In Mozambique, the migratory 
phenomenon has occurred since the beginning, and has been growing with the unfolding of the country's history, being, therefore, a phenomenon that has been growing and posing challenges in the management of this phenomenon.

According to the author above, this unusual flow of immigrants has created a controversial sociopolitical and economic impact, making migratory flows one of the most visible dimensions of the global globalization process, as migrations as social, economic phenomena and political, constitute mechanisms for linking cultures and peoples. Consequently, changes in the geographies of ethno-linguistic relations in various contexts.

Mozambique has been preferentially appealing to migrants in general, and to Africans in particular, some of whom have entered irregularly, taking advantage of the porosity of land borders, the long coastline and corruption. These weaknesses contribute to the entry or facilitation of massive entry of migrants into Mozambique, whether in a legal or illegal situation.

Francisco (2018) and Seda (2017), considers that illegal immigration, transnational organized crime including cross-border, although not a new phenomenon, the networks dedicated to these modalities have significantly evolved their modus operandi, considering itself as one of the greatest threats to the Internal Security of States today in general and of Mozambique in particular, requiring from the border security forces a redoubled effort to guarantee the inviolability of state borders.

Therefore, the challenges are still enormous for the State, and it is therefore important and imperative to have an integrated and coordinated management of borders, in ways that each stakeholder involved in border control action, work and collaborate to combat illegal immigration, promoting safe, regular and orderly migration.

\section{Research Problem}

In recent years, Mozambique has seen a considerable number of irregular migrants trying at all costs, both through official entry points, as well as through unofficial points, this time favoring the traffic of human beings and the smuggling of goods, including of wildlife such as ivory and other prohibited products. This irregular entry of migrants causes considerable damage to the country, not only for the national security area, as well as the economic area, when no declaration of goods brought by them is obtained from them, negatively contributing to the payment of taxes, causing the Mozambican authorities linked to the administration of migrants, do not have the quantitative dimension of the losses that the State suffers, allied to its weak capacity to control the entry, stay and exit of foreign migrants.

From the above, the research problem lies in the fact that the various security forces operating at the border have poor integrated border management, significantly limiting the ability of the various border actors to check or identify suspicious persons at entry points and/ or exit.

In view of the identified problem, this study was aimed to understand how an integrated border management can contribute to combating illegal immigration in Mozambique, as well as related crimes, associated with the phenomenon of illegal immigration.

\section{Research Focus}

To understand the overall context of border management in Mozambique, it is important to provide an overview of the relevant legislative framework that governs border management in the country. Mozambique is a member of the African Union (AU) and the Southern African Development Community (SADC), and in the context of facilitating the free movement of people and goods, Mozambique ratified, in 2005, the Agreement on the Free Movement of People and Goods in Mozambique. SADC region, having established Visa Waiver Agreements

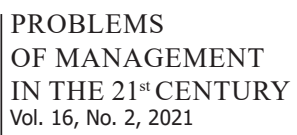


PROBLEMS

OF MANAGEMENT

IN THE $21^{\text {st }}$ CENTURY

Vol. 16, No. 2, 202

with all SADC countries except the Democratic Republic of Congo (DRC) and Madagascar. In similarly, at the continental level, signed on March 22, 2018, and still awaiting ratification by the Government, the agreement on the free movement of people, right of establishment and residence in Africa. When this agreement is ratified, it will allow greater mobility of citizens in Africa, which requires from all actors involved in border management, greater articulation, so that there are no violations of norms.

At the bilateral level, agreements are being made for the establishment of one-stop border posts, with South Africa, across the borders of Lebombo and Ressano Garcia, with Malawi and Tanzania, as the solution found for integrated border management, in which consultations should be carried out by the various actors involved in immigration/customs clearance.

It is particularly important to emphasize that with integrated border management, it will not only combat illegal immigration, but also strengthen regional trade and economic links, on a regular and secure basis, through a spatial focus on Mozambique's economic corridors. The Beira and Nacala corridors link central and northern Mozambique with Malawi, Zimbabwe, Zambia and by extension Botswana and the Democratic Republic of Congo. These two corridors can be considered fundamental for developing Mozambique, as an efficient logistics and port gateway to the region.

Therefore, with effective integrated border management, access to the country through the corridors can contribute to strengthening connectivity in southern Africa and improving the region's competitiveness, thus contributing to the strengthening of regional integration as well as increased exchanges. trade and investment, in turn contributing to structural transformation, job creation and poverty reduction in southern Africa, this time promoting safe, regular and orderly migration.

\section{Research Methodology}

The research adopted a qualitative approach, which consisted of a bibliographic analysis of the available material, a documental analysis of Mozambique's internal laws and regulations to manage migration processes, as well as available statistical data that gave the idea of the entity of the phenomenon in question. Such information was crossed with a direct observation work that lasted about a year and allowed a better understanding of the type of management of the Mozambican borders and its failures, highlighting their porosity.

\section{Legislative Framework}

As a sovereign state, Mozambique has a set of laws and legal principles that guide the action of the state in relation to the phenomenon of immigration, although no organic and systematic migration policy has yet been approved and is in force.

Thus, in order to guarantee the realization of the rights and duties of foreign citizens, Mozambique has, at the internal level, several legal instruments, namely:

- Law No. 5/93, of December 28, which establishes the Legal Regime of Foreign Citizens, establishing the respective norms for entry, permanence and exit from the country, rights, duties and guarantees.

-Decree $n .^{\circ} 108 / 2014$, of December 31st, which approves the Regulation of Law n. ${ }^{\circ}$ 5/93, of December 28th.

- Law No. 6/2008, of 9 July, which establishes the legal framework for preventing and combating trafficking in persons;

- Law No. 23/2007, of 1 August, which defines the mechanisms for hiring foreign labor; 
-Law No. 21/91, of 31 December, which approves the Refugee Statute;

-Decree No. 33/2007, of 10 August, which approves the Regulation on the Process for Attributing Refugee Status in the Republic of Mozambique.

At the international level, Mozambique ratified the 1951 Geneva Convention on the Status of Refugees and the Additional Protocol to the 1967 Geneva Convention, through Resolution 11/88, of 25 August.

Furthermore, Mozambique observes the Universal Declaration of Human Rights (UDHR) and the International Covenant on Civil and Political Rights (IPDCP), with regard to freedom of movement (articles 13 of the UDHR and 12 of the ICCPR).

Despite a relatively rich legislation, it is widespread, and this may not help in the effective management of migratory flows, due to the lack of systematicity and the lack of legislative updating, given the recent phenomena related to illegal migration in Northern Mozambique of Islamic-based terrorism, fed by Tanzanian citizens, from the Great Lakes, Congo, etc.

\section{Theoretical Framework}

The world is inhabited by a multiplicity of people and, every day, people circulate, motivated by various reasons, fundamentally economic, social and political. These reasons have increasingly fed the mixed migration flow of citizens. According to the IOM (2009, p.40), Migration is understood to be the process of crossing an international border or a State, a population movement that comprises any movement of people, regardless of the extent, of the composition or from causes; includes the migration of refugees, displaced persons, uprooted people and economic migrants.

In view of the above concept, migration is considered to be the movement of people from one place to another, which may occur within the same country, with greater emphasis from rural to urban areas and, between different countries, being designated as regional/continental and international migrations.

In the past, the migratory flow occurred with greater intensity from underdeveloped countries to developed countries, where the main cause of migration was the improvement of social well-being, seeking opportunities, or from developed countries to underdeveloped countries, and rarely from underdeveloped countries to other underdeveloped countries.

However, this scenario, although the migratory flow from underdeveloped to developed countries still prevails, tends to be partially changed today, and the clear proof of this inversion trend and this growing trend of illegal immigration that wants to reach Mozambique, at all costs, by the way, most citizens in this situation, come from underdeveloped countries to another underdeveloped one.

Over the past five years the landscape of international migration has suddenly changed. If, according to the World Bank (2015), migrations until the middle of the last decade occurred in all directions, with $37 \%$ of the total concentrated in the South-South space, 35\% towards the South-North direction, 23\% North - North and finally 5\%, in the North-South direction, in 2020 we have the following table, according to data of the United Nations: a considerable absolute increase, totaling 281 million migrants, against 173 million in 2000 and 221 million in 2010. Today, about $2 / 3$ of international migrants live concentrated in 20 countries in the north of the world, among which United States (with 51 million) and Germany (with 16 million). The country with the largest number of people living abroad is India (18 million), followed by Mexico, the Russian Federation and China.

The reasons that make migrants move from their countries of origin can be natural, economic, political, religious, ethnic. According to Guia (2008, p.33) since the beginning of its 
Zainadine João DANANE. Integrated border management as a vector to combat illegal immigration in Mozambique

PROBLEMS

OF MANAGEMENT

IN THE $21^{\text {st }}$ CENTURY Vol. 16, No. 2, 2021

existence, man has been trying hard to survive the adverse conditions of nature, seeing himself frequently forced to migrate.

Due to the geographical location of Mozambique south of the equator in the southern African region, and which is distant from the horn of Africa, the Great Lakes region, as well as from western Africa, it is important and pertinent to understand what really makes the African move within the same continent, in this case, the movement of several foreign African citizens to Mozambique, considering and considering that Mozambique is not a developed country, if we invoke the hypothesis of better living conditions, as the main cause of migration.

Based on the ideas of Guia (2008), he considers globalization, tourism, new information and communication technologies and the report of experiences lived by other migrants to be elements that provide greater dissemination and attractive aspects of other cultures, thus contributing to the occurrence of international migrations. Therefore, Castels (2005), defends migrants, through the dynamization of international migratory flows as an integral part of the globalization process, thus allowing the liberalization of capital and goods flows, making them assume as driving vectors for global economies.

That is why Patrício (2016) considered that the displacement of individuals to different territorial spaces within and across borders is increasingly accentuated and assumes proportions that affect most regions of the African continent, where Mozambique is not exempt from the phenomenon. For, according to Faria (2015, p.37) no country can be considered alien to the contemporary migratory phenomenon, in which the old dichotomy between countries of origin ("senders" of migrants) and destination ("receivers" of migrants) gave way to a scenario in which countries experience, simultaneously, waves of emigration and immigration.

The diversity of flows makes many countries, at the same time, points of origin, transit and destination for migrants. In this line of thought, it is clear that there is a need to reinforce the mechanisms for controlling the entry of foreign citizens, as a way of guaranteeing that citizens who intend to enter the country comply with the minimum requirements required, according to the purpose of their entry.

However, Velazquez (2000), citing Ravenstein, speaks of the first systematic principles that explain the dynamics of migration, based on five general propositions, namely: the relationship between migration and distance, differentiating short and long-distance migrants, with male predominance in long-distance migrations and female predominance in short-distance movements. Stage migration, in which he notes that migrants will first come from nearby villages towards the center of attraction or urban area, but as industry and commerce continue to grow, migrants will also be attracted from very distant villages. Rural-urban differences in the propensity to emigrate, in which the urban population is less likely to emigrate than the rural population. Developments in technology and means of transport lead to an increase in migration. Last but not least, the reason behind the migration process, says Ravenstein, is an individual rational decision based on calculations of migration costs and benefits.

According to Velazquez (2000), economic factors in the place of origin operate as "push" forces which, in combination with what he calls "pull" factors in the destination, explain migratory flows. However, Faria (2015, p.38), grouped the causes of contemporary migrations into two categories: the first of those who move for economic reasons, that is, in search of a "better life", responding to the so-called factors of attraction (pull factors), such as the prospect of better living conditions they will find in the destination countries, in terms of job offer, wage and labor standards and the possibility of economic ascent.

The second category represents those who are, in varying degrees, forced to leave their countries of origin, thus responding to repulsion factors (push factors), which make their stay in their countries impractical, such as: natural disasters, civil conflicts or political, racial or religious persecution. 
Therefore, these two categories of factors of attraction and repulsion of migrations, in a consensual way, are defended by several authors, among them Guia (2008) that groups in economic reasons and in non-economic reasons (family reunification, security and defense of human rights, avoidance of political, religious, racial persecution, etc.), for the occurrence of migrations, and Castles (2005) that highlights globalization through the broadening, deepening and acceleration of interconnections on a global scale, which makes the cross-border flows and the transnational network. According to the causes presented above, immigration can be legal or illegal.

\section{Research Results}

\section{Brief History of Illegal Immigration in Mozambique}

According to Cadeado et al (2009), with the culmination of the civil war in Mozambique and the fall of the Apartheid regime in South Africa, on the threshold of the 1990s, Mozambique entered the immigration route, on a large scale, as a transit corridor for legal and illegal immigrants to South Africa, having generated a high migratory flow, both for citizens returning to the country, as well as for those intending to reach other neighboring countries through Mozambican borders.

With the signing of the General Peace Agreement in 1992, Mozambique has witnessed a considerable mixed flow of foreign citizens, motivated by the relative political stability that characterized the country, after the General Peace Agreements of 1992, compared to the countries of West Africa, from the region of the great and the Horn of Africa, who were seeking asylum in Mozambique, which in the 1990s dictated the installation of a refugee reception center in Nampula Province, to house a group of citizens who, for reasons of greater force, felt - if obliged to leave their countries of origin and choose Mozambique as their Country of residence. However, Seda (2017), considers that this increasingly high trend of migratory flow has led countries to carry out legislative reforms with a view to better control of the movement of people and goods, with a focus on combating illegal immigration and transnational crime.

The entry of legal and illegal immigrants into Mozambique takes place by air, land and sea. However, according to Cadeado et al (2009), illegal immigrants arrive in Mozambique, preferably by land, due to the weakness of supervision and control of the extensive border. Indeed, this situation makes it possible to circumvent authorities, but also facilitates the action of organized networks for the recruitment and facilitation of illegal immigration.

According to the author above, the land immigration route runs north and center towards the south. Indeed, the border districts of the North (Cabo Delgado and Niassa) and Center (Manica, but mainly Tete) have been the main entry points of illegal immigrants, to that end, immigrants have bribed, for example, long-haul truck drivers. In other cases, immigrants are hidden in the middle of goods or in tanker trucks as a way to outwit immigration authorities and border guards. Tete Province is considered one of the most vulnerable to illegal immigration.

Illegal entries are also made at various points away from the official location of the border posts. Thus, the entry of illegal immigrants into Mozambique cannot be seen as a uniquely Mozambican problem. This is also a problem in Zambia but mainly in Tanzania and Malawi where most illegal immigrants are supposed to enter, as well as in South Africa, where these illegal immigrants mostly intend to enter in search of a job. Furthermore, the SADC (Southern Africa Development Community) itself does not seem to be in a position to help in an integrated policy for managing internal migration flows to its member countries.

\author{
PROBLEMS \\ OF MANAGEMENT \\ IN THE $21^{\text {st }}$ CENTURY \\ Vol. 16 , No. 2, 2021 \\ 79
}


Zainadine João DANANE. Integrated border management as a vector to combat illegal immigration in Mozambique

PROBLEMS

OF MANAGEMENT

IN THE $21^{\text {st }}$ CENTURY

Vol. 16, No. 2, 2021

\section{The Management of Illegal Immigration in Mozambique}

Immigrants in general are settled in all the provinces of Mozambique and in places of mostly economic interests, with emphasis on those that allow greater circulation of currency or the existence of valuable natural resources that are easy to exploit.

In this context, Maputo City, Maputo Province, Tete, Pemba and Nampula are considered points of greatest agglomeration of foreigners, a scenario that has contributed to the attraction of illegal immigrants, and part of these have used Mozambique as a transit country to the Republic of South Africa, with emphasis on Asian citizens, namely Pakistanis and Bangladeshis, and some Africans from Somalia, Ethiopia, Malawi and Zimbabwe.

According to Cadeado et al (2009), migration is a transnational phenomenon, whose management exceeds the capacity of each State, requiring the involvement of several actors, namely the State, international organizations, civil society, local authorities, the community and others.

To face the phenomenon of illegal immigration, the work of direct observation, as well as conversations with specialized officials led to the conclusion that SENAMI has been implementing the following measures:

The reinforcement of entry control measures, the intensification of inspection actions for the permanence of foreign citizens in the national territory;

Development of training and capacity building actions for the staff on the subject in focus

- Reinforcement in human resources, qualified materials;

- Provide members with mechanisms and techniques for identifying illegal immigrant hotspots.

However, according to the direct observation made, the work of coordination and communication with other areas that contribute to combating and preventing illegal immigration, such as the forestry resources sector, customs, defense ministry and others, still seems to lack. To this day, the idea defended by the first President of Mozambique, Samora Machel, according to which the Defense and Security Forces must boil at the same temperature, reinforces the idea of constant adequate coordination to combat an evil that plagues society. Mozambican, thus avenging the idea that all border security forces must work hand in hand to fight illegal immigration.

According to the IOM (2009, p.42), illegal immigration is a movement that occurs outside the scope of the regulatory norms of the sending, transit and host countries. There is no clear or universally accepted definition of irregular migration. From the perspective of destination countries, entry, stay and work in a country is illegal, whenever the migrant does not have the necessary authorization or documents required by immigration regulations relating to entry, stay or work in a given country.

From the perspective of the sending country the irregularity is seen in cases where, for example, a person crosses the international border without a valid passport or travel documents or does not meet the administrative requirements to leave the country. There is, however, a tendency to use the term "illegal migration" in cases of migrant smuggling and human trafficking.

Therefore, the above ideas are in accordance with the provisions of Mozambican legislation and in force, through law 5/93 of December 28, which considers illegal immigration as the entry, stay and exit of national and foreign citizens without observing the migratory formalities, and SENAMI is responsible for ensuring the application of measures provided for in the immigration legislation in force in the country, to combat them. This phenomenon leads to a reflection on its evolution, which must be from multiple points of view beyond the security forces. 
According to the above law, illegal immigration into the Republic of Mozambique is considered whenever a foreign citizen, who is not authorized by the competent authorities, enters, transits, remains or resides, or is in any of the following circumstances:

- Does not have a legally required travel document;

- Has not entered the Post officially established by law;

- Has not been subject to the immigration procedures of the competent authorities at the Crossing Post;

- Use false identity, false or forged travel document;

- Re-enter during the term of an interdiction measure;

- Remains in the country beyond the legally established period;

- The residence permit or residence permit has been revoked.

However, not all citizens who intend to enter Mozambique are illegal, as according to data held by SENAMI, just over 50,000 foreign citizens of different nationalities reside legally in Mozambique. However, during the first nine months of 2021, immigration authorities detained around 4000 for various migratory offenses, notably illegal immigration, which culminated in the repatriation of just over 3,338 foreign citizens. From this number, the main causes that dictated repatriation were clandestine or illegal immigration, and illegal stay in the country, and it can be inferred that a large number of foreign citizens enter the country illegally and or remain illegally in the country.

These data on illegal immigrants do not reflect the reality of the chronic problem, as most illegal immigrants are not counted when they are not questioned. Therefore, SENAMI is trying to carry out bold and energetic measures with a view to combating the phenomenon of illegal immigration, through an exemplary punishment of those who help illegal immigration. This type of crime is punishable in accordance with the Mozambican penal code, imposing severe penalties on those involved in this crime, as well as seizing and converting property held by immigrants or facilitators to aid illegal immigration in favor of the State.

An apparently contradictory element is the high rate of SADC citizens who suffer from illegal immigration, when the Mozambican state, with the other SADC states, through bilateral agreements, signed visa exemption agreements, with a view to guaranteeing free movement people and goods, with the ease of obtaining visas to arrive at more than 40 official border posts. Therefore, foreign citizens who claim to enter the country illegally, raise a series of doubts regarding their real intentions, which may be corroborated with the idea of being malicious individuals, with a view to perpetuating crimes in the destination countries.

According to data held by SENAMI, of the total of those questioned in the first nine months of 2021, the following nationalities are highlighted: Malawian, Ethiopian, Zimbabwean, Rwandan, Burundian, Pakistani, Bangladeshi, Tanzanian, Nigerian, Zambian, Senegalese, Guinean and Congolese, as the most expressive. With the above nationalities, it is clear that despite the joint efforts of the SADC region to facilitate the free movement of people and goods in the region, those who claim to use illicit ways to migrate, which leads to a reflection on whether in fact the nationalities evoked are they really the real ones? Isn't it the case of false declarations to hide true identities? Will those questioned in the situation of illegal immigrants not return later to enter the country? Is there a solid database that makes it possible to identify whether the citizens questioned and repatriated are not the same ones who returned to the same situation as before? This challenges the border authorities, the introduction of dactyloscopy techniques, in ways that can be held criminally responsible if such is the case of repeat offenders entering the country illegally.

One of the biggest difficulties that the border security forces have in managing migratory flows, especially illegal ones, are organized crime networks, as most illegals do not use official crossing points, which would make it difficult for them to easy penetration into national territory. However, there is an urgent need for greater commitment and commitment from other border 
PROBLEMS

OF MANAGEMENT

IN THE $21^{\text {st }}$ CENTURY Vol. 16, No. 2, 202

security forces, especially where no official posts have been established, where crossings are made or controlled by the Border Police, as, according to Cadeado et al, (2009), and Francisco (2018), illegal immigration is one of the greatest threats to territorial integrity, as well as public order and tranquility, and may be contributing to the import of new modus operandis and sophistication of related crimes, such as aid to illegal immigration , recruitment of illegal labor; trafficking in persons; abduction; kidnapping, among others.

\section{A Possible Solution: Integrated Mozambican Border Management}

As shown in the above analysis, whether from a legislative point of view or from an internal organization, SENAMI is showing difficulties in containing an illegal migratory flow that increasingly threatens the security of the State and its citizens. That is why, according to the research carried out, an integrated border management could be a way to improve an increasingly worrying situation.

According to the IOM (2009, p.31), integrated border management is the facilitation of authorized flows of business people, tourists, migrants and refugees and the detection and prevention of the illegal entry of foreigners into a given country. Border management measures include the imposition of visa requirements, sanctions for transport companies that bring irregular foreigners into the territory and maritime interdiction. International standards require a balance between facilitating the entry of legitimate travelers and preventing the entry of travelers who have secondary intentions or who present invalid documentation.

Mozambique officially has 56 crossings, including air, land and sea, unevenly distributed throughout the national territory, with the provinces of Cabo Delgado and Tete, the ones with the highest number of crossings, with 9 and 11 respectively. Of the 56 crossing points, 44 are duly authorized and equipped to issue border visas upon arrival.

However, according to information provided by the National Migration Service, the Tete and Cabo Delgado Crossing Posts are the ones with the highest number of illegal immigrants, out of just over 2000 (two thousand) foreign citizens repatriated from January to June 2021, of different nationalities and migratory offences, against about 1000 (one thousand) citizens repatriated in the same period of the previous year, which represents an increase of around $50 \%$. This corroborates the idea of a growing existence of foreign citizens who choose to follow illicit routes to enter, stay or transit the country.

However, it is necessary to show some engagement of the border security forces in combating the phenomenon of illegal immigration, which in my opinion, the forces could do much more, if they are working in a coordinated manner, where each member, in their field of action, should take ownership of the phenomenon as its own, in defense of the country's sovereignty, as it has been reported cases in which the Border Police facilitates the crossing of citizens illegally, as well as members of SENAMI.

Let's see, how is it justified to be questioned foreign citizens in the country, in the middle of the journey, in a public transport bus without a travel document? The direct observation work carried out showed that, when questioned, they claim to be foreign citizens and that they crossed, some in official posts and others in simplified posts, under the management of the Border Police, which refers to a commitment of the various actors in a coordinated manner, in order to avoid - if the challenges related to illegal migration do not jeopardize the security of Mozambican citizens.

At border posts, members of several institutions function, each according to its nature and specificity, and carry out their tasks, albeit in an uncoordinated manner, but they communicate consistently to ensure that there is good coordination at the border, according to the nature and dimension of each border. Each institution operating on the border has its own function, among which the following stand out: 
- National Migration Service (SENAMI) - the migration service, linked to the Ministry of the Interior, is responsible for controlling entry/exit and permanence in national territory; issuance of travel documents to Mozambican citizens and foreign residents and, granting of entry visas at borders. SENAMI is present at all ports of entry in the country.

Pursuant to paragraph 1 of article 2, as well as article 4 of law 4/2014, of 5 February, which creates the National Migration Service (SENAMI), as a public service of a paramilitary nature integrated in the Ministry that oversees the area of Migration, with powers to control migratory movement across national borders, oversee the permanence of foreign citizens in the territory national, issue travel documents for nationals and issue residence documents for foreign nationals.

It is also incumbent upon SENAMI to guarantee the granting of entry visas and residence permits for foreign citizens, who are not subject to any restriction order issued under the law, pursuant to paragraph b) of paragraph 3, of article 5 (Specific competences) of Law 4/2014, of February $5^{\text {th }}$

The process of migration from one state to another is subject to predetermined norms and procedures, in the form of legal norms that each country sets. Failure to comply with these rules constitutes a migratory offense, according to typicality, however, the most common is that of illegal or irregular immigration, in which Mozambique, like other countries, is not oblivious to the phenomenon of illegal immigration.

- General Directorate of Customs - subordinated to the Ministry of Economy and Finance, is responsible for carrying out customs control of goods, collection of customs duties and tax revenues. Customs is present at all official Points of Entry across the country;

- Border Police (Border Police) - subordinated to the Ministry of Interior, it is responsible for patrolling the border and preventing irregular crossings. In areas/crossing points along the border where migration officers are not present, the border police are also responsible for controlling the border crossing (for members of the border community who live within 10 to 15 kilometers of the border radius).

According to law 16/2013 of 12 August, law of the Police of the Republic of Mozambique, the Border Police is responsible for ensuring order, security, public tranquility and the inviolability of the state border; act in the first line of protection of the state border in coordination with the other Defense and Security Forces; combat illegal immigration, smuggling, trafficking in people and human organs, trafficking in drugs and various goods along the state border; ensure the necessary measures for border surveillance, as well as the control of the movement of people and goods.

- Department of Health (National Directorate of Health) - subordinated to the Ministry of Health (MS), it is responsible for providing medical assistance at the borders (for example, providing first aid, controlling and/or applying vaccines against yellow fever in if necessary, providing information on how to prevent certain diseases such as HIV / AIDS, Malaria or Ebola) and referring all cases that need more medical assistance to the nearest health post. Now, more than before necessary, with the emergence of covid - 19, it deems - if it is pertinent, the allocation of Health personnel in all Crossing Posts, especially those with the highest flow, this time allowing the tracking of all citizens crossing borders, in the observance and compliance with the sanitary protocol.

- Ministry of Agriculture and Food Security - linked to the Ministry of Agriculture and Rural Development (MADER), it is responsible for evaluating all food products entering the country. Not present at smaller border crossing points;

However, despite the above mentioned institutions, given adverse conditions, not all of them are structured equally, in terms of composition, and even those that have all the staff and fully functioning, illegal immigration occurs, which refers to the need for an integrated border management, where all actors from the different sectors are challenged to combat this evil 
PROBLEMS

OF MANAGEMENT

IN THE $21^{\text {st }}$ CENTURY Vol. 16, No. 2, 2021

with all rigor, as Seda $(2017$, p.8) puts forward, that border management requires permanent coordination and sharing of fundamental information between the different sectors, thus allowing the various institutions to coordinate their activities to better control illegal migration, human trafficking, smuggling and transnational organized crime in general, thus assuming the role of guarantors of the sovereignty, thus allowing the stagnation of illegal immigration and related crimes associated with it.

It seems that the issue of the integrated management of complex phenomena, by the Mozambican State, still represents a challenge, as it is also happening in relation to phenomena of different nature, from environmental disasters to terrorism in the North of the country (Bussoti, 2021).

According to Cadeado et all, (2009), the difficulty of institutional coordination between the main agents or state actors makes the country vulnerable to this problem. This vulnerability is a problem that can be exacerbated by illegal immigration that has been growing, but whose magnitude and holistic impact is realistically unknown in Mozambique.

It is clear that an integrated and coordinated border management helps to reduce cases of illegal immigration, as well as the increase in tax revenues, through the payment of taxes that citizens have declared to enter the country, and allows consequently, check that citizens entering the country do not pose a threat to national sovereignty and public health.

For a better integrated border management, it is increasingly important to invest in the training of different actors, in which officers should be trained in key areas of integrated border management, such as Data Management and Intelligence / Risk analysis and management, which allows selecting imports and exports suspected of containing goods with evidence of fraud for non-intrusive inspection and from this for physical inspection when applicable; Detection of security documents and fraud; trafficking and smuggling; Protection of Vulnerable Migrants and Humanitarian Management of Borders, among other elements.

The understanding that can be established is that of border officials to work in a coordinated and integrated manner, as a way to prevent and reduce the occurrence of illegal immigration in Mozambique, a fact that is supported and defended by the European Union, through the Resolution of the Council of Ministers No. 104/2017, of 17 July, which establishes that the National Strategy for Integrated Border Management ensures the balance between internal security, streamlining of border crossing and border management issues in favor of the Area of Freedom, Security and Justice always from a humanist perspective and respect for the fundamental rights of citizens, but it is important to put the necessary means and equipment at their disposal, for a better integrated management of borders, as well as triggering actions aimed at a change management process, with greater focus of minds.

Along with the European Union, Angola, which has legal provisions for border coordination, Mozambique also has the COMAF (Intermenstrual Commission for the Sea and Borders) created through Presidential Decree No. 3/2007 of 8 March, as an organ of the Council of Ministers for the coordination of actions to be developed on the sea and borders, within the framework of the defense of sovereignty and the establishment and maintenance of friendly relations with other neighboring countries, in particular. With this commission established, it is clear once again that the coordinated management of borders has multiple advantages, as it allows the introduction of different and innovative forms of border management, where the traditional model of border management is broken for a modern vision that it is supported by information and communication technologies, in which immigration and customs clearance can be carried out, which makes it possible to change from manual to electronic processes.

The question that does not want to remain silent is: Why then the unusual occurrence of illegal immigration, even in the face of legally established devices and institutions? Is it for lack of commitment from members? Or due to the ineffectiveness of COMAF? 
In order to achieve the efficiency of government institutions, it is recommended to maximize the use of information technologies to share information and improve management processes, which presupposes a modernization of services.

\section{Conclusions and Implications}

Human beings always feel the need to move from one point to another, often motivated by economic, political and social factors. However, when this mobility is done on a regular basis, it may not put the designs of sovereignty at risk, which sends border managers to a challenge of sectoral coordination, to prevent the occurrence of cross-border and transnational crimes, including illegal immigration.

With the implementation of integrated and coordinated border management, it will allow the introduction of different and innovative forms of border management, breaking from the traditional model of border management to a modern vision, the basis of ICTs, in which clearances can be carried out. immigration and customs, with security and some reliability, without using manual processes for both migration and customs clearance for electronic processes, and with the involvement of all, to combat illegal immigration and tax evasion.

With this research, it is expected that the border control entities improve their actions in a coordinated and joint manner, guaranteeing the inviolability of the border and consequently the prevalence of illegal immigration and the reduction of related crimes, associated with illegal entry into the country.

The implementation of Integrated Border Management is always aimed at strengthening internal security, through the reduction of irregular immigration, at the level of borders, as well as the suppression of cross-border crime. This research highlights the relevance of coordinated border management, through the involvement of different stakeholders, as a vector to combat illegal immigration, as well as related crimes.

At the international level, this research showed the difficulties of Mozambican State faced before the growing phenomenon of illegal immigration in Mozambican territory. Nevertheless, the study here presented was able to show also some recent strategies implemented by Mozambican authorities in order to fight illegal immigration, as well as the first successes coming from this new, integrated strategy. Today, the challenges are very serious, due to the penetration of Islamic terrorism in the North of Mozambique; an important role in such attacks has been played by foreign citizens.

For a better management of the phenomenon, it is urgent to join synergies with other neighboring countries, where the majority of illegal immigrants use them as transit countries. With a negative impact on the economy and public safety in transit countries, the permanent deepening of research is deemed pertinent, in terms of illegal immigration and public safety in destination or transit countries, requiring the sharing of information at different levels with the various border actors.

\section{References}

Barca, A. (1992). Physical profile: Collection, know Mozambique: Scholar Editor.

Bussotti, L. (2021). Managing terrorism in Africa. Problems of Management in the $21^{\text {st }}$ Century, 16(1), 4-6. https://doi.org/10.33225/pmc/21.16.04

Cadeado, C., Enilde Sarmento, E., Chingotuane, E., \& Nhachete, P. (2009). Immigration in Mozambique: Socio-political, economic and cultural impacts. Maputo.

Castles, S. (2005). Globalization, transnationalism and new migration flows. Edições Fim do Século.

Daily Portuguese Republic, 1st series - No. 136 - 17 July 2017. 
Zainadine João DANANE. Integrated border management as a vector to combat illegal immigration in Mozambique

PROBLEMS

OF MANAGEMENT

IN THE $21^{\text {st }}$ CENTURY
Vol. 16, No. 2, 2021

Faria, M. R. (2015). International migration at the multilateral level. Alexandre de Gusmão Foundation http://funag.gov.br/loja/download/1130-Migracoes_internacionais_no_plano_ multilateral_23_10_2015.pdf

Francisco, F. (2018). Study of the security systems of state borders in Mozambique in the face of new threats to internal security: New University. https://run.unl.pt/bitstream/10362/63044/1/Francisco_2019. pdf

Guia, M. J. (2008). Immigration and criminality. Almedina .

IOM (2009) Glossary on Migration' International Law on Migration No. 22. Geneva: IOM UN Migration, retrieved 07/11/2021 from: https://publications.iom.int/system/files/pdf/iml_34_glossary.pdf

Law 4/2014 of February 5th, creates SENAMI.

Law 16/2013 of 12 August, Law of the Police of the Republic of Mozambique.

Patrício, G. (2016). Mozambique: driving internal and international migrations, Interspace, 2(5), 78-101. http://www.periodicoseletronicos.ufma.br/index.php/interespaco/article/view/5266/3200

Grajaú/MA v. 2, n. 5 p. 78-101 Jan./Apr. 2016.

Seda, F. L. (2017). Border management in Mozambique. Scholar Editor.

Presidential Decree ${ }^{\circ} 3 / 2007$ of 8 March.

Velázquez, F. (2000). Approaches to the study of international migration: A review. Estudios Fronterizos, 1(1). https://ref.uabc.mx/ojs/index.php/ref/article/view/298

Received: November 10, 2021

Accepted: December 05, 2021

Cite as: Danane, Z. J. (2021). Integrated border management as a vector to combat illegal immigration in Mozambique. Problems of Management in the $21^{\text {st }}$ Century, 16(2), 74-86. https://doi.org/10.33225/pmc/21.16.74

Zainadine João Danane

PhD Candidate in Peace, Democracy, Social Movements and Human Development, Researcher, Technical University of Mozambique, Albert Luthuli 418/438, Avenue, Maputo, Mozambique.

E-mail: zainadinedanane@gmail.com

ORCID: https://orcid.org/0000-0001-5275-6641 